\title{
COVID-19 in rheumatoid arthritis cases: an Iranian referral center experience
}

\author{
Soraya Shadmanfar ${ }^{1,2} \cdot$ Nematollah Jonaidi-Jafari $^{1} \cdot$ Ramezan Jafari $^{1,3} \cdot$ Zeynab Rastgar-Moqaddam $^{4} \cdot$ Amin Saburi $^{1,5}$ (D)
}

Received: 18 July 2020 /Revised: 9 October 2020 / Accepted: 12 October 2020 / Published online: 20 November 2020

(C) International League of Associations for Rheumatology (ILAR) 2020

\begin{abstract}
Coronavirus infections, known as COVID-19, can induce a fatal respiratory system infection and also affect other organs, such as the kidney and heart. The mortality rate has been estimated between 1 and $5 \%$ in previous reports; however, the mortality and morbidity can be higher in patients with the immune-deficiency condition. Rheumatoid arthritis (RA) is one of the most rheumatoid disorders, and it is important to report their clinical and paraclinical data when affected with COVID-19. Evidence about their laboratory and radiologic findings is limited. In this case series, 10 cases of chronic and approved rheumatoid arthritis (RA) affected by COVID-19 are presented. Only $40 \%$ had dry cough, but myalgia and weakness as the general first presentation of infections was reported in most cases (80\%). Gastrointestinal symptoms, including nausea/vomiting, diarrhea, anorexia, and abdominal pain, were reported in 50\% of individuals. In blood cell count, $30 \%$ of cases had thrombocytopenia, and ESR in all cases was positive. Abnormal CRP and elevated LDH were seen in $90 \%$ of cases. In HRCT assessment, all cases had an abnormal parenchymal pattern, and 90\% of cases presented the usual pattern of COVID-19 (bilateral multifocal GGO/consolidation). Although it is a limited report, these findings are helpful for comparison of clinical and paraclinical cases in RA cases with normal cases.
\end{abstract}

Keywords Coronavirus $\cdot$ COVID-19 $\cdot$ Pneumonia $\cdot$ Rheumatoid arthritis $\cdot$ SARS-COV2

\section{Introduction}

COVID-19, as a pandemic infectious disease, has caused great fear and anxiety among the international communities in recent months; however, the issue seems more critical when reports suggest that the mortality in cases with underlying diseases, such as diabetes, heart, and lung problems, as well as consumers of immunosuppressive drugs, is higher [1]. There are few reports on clinical and paraclinical

Amin Saburi

aminsaburi@yahoo.com

1 Health Research Center, Life Style Institute, Baqiyatallah University of Medical Sciences, Tehran, Iran

2 Faculty of Medicine, Rheumatology Department, Baqiyatallah University of Medical Sciences, Tehran, Iran

3 Faculty of Medicine, Radiology Department, Baqiyatallah University of Medical Sciences, Tehran, Iran

4 Faculty of Medicine, Iran University of Medical Sciences, Tehran, Iran

5 Dr Saburi Radiology \& Ultrasound Clinic, Mashhad, Iran characteristics of rheumatoid disorder cases affected by COVID-19, which have a very limited population [2-4]. Firstly, it seems that cases with rheumatoid arthritis (RA), as one of the most common rheumatologic disorder, are more vulnerable to COVID-19, and morbidity is more expected due to lung involvement as one of the prominent and important involvements in such cases, but further studies refuted this hypothesis [5,6]. Iran is one of the largest centers of disease in West Asia that, at the time of writing, more than 160,000 people have complained about the disease. In this work, as the first from Iran, we report 10 cases of rheumatoid arthritis whose COVID-19 has definitely been confirmed in laboratory tests.

\section{Case presentation}

In this case series, 10 cases of chronic and approved rheumatoid arthritis (RA) affected by COVID-19 are presented. Baqiyatallah Hospital is a university hospital in the capital of Iran, Tehran, selected as a referral center for COVID-19 on the first days the disease announced. More than 10,000 
COVID-19 cases were diagnosed, managed, treated, and hospitalized in this hospital.

The rheumatologic ward of the hospital as a referral center for rheumatologic cases affected by COVID-19 was under careful observation. RA cases referred to the hospital who had the interest to take apart in the research project were selected for more assessment, and their data were collected by a methodological team.

The mentioned criteria were met by 13 cases, 3 of whom had considerable missed data and thus were excluded. Ten cases were included in the study; their clinical data and paraclinical data (including radiologic and laboratory) were presented as in Tables 1 and 2, respectively.

There are some considerable points in this group to be noted:

Most cases had an age greater than 55 years old and were female. Methotrexate and prednisolone were the most frequent medication used. Four cases used hydroxychloroquine as immune moderators (Table 3). Hydroxychloroquine was used by 4 cases for relieving the COVID-19 symptoms and preventing its progression; nevertheless, these cases showed the radiologic and clinical features of COVID-19 (Table 2).

Only 4 cases had dry cough, but the most frequent symptoms were fever and myalgia (7/10), dyspnea $(5 / 10)$, and GI symptoms, including anorexia (2/10), nausea $(3 / 10)$, and diarrhea $(2 / 10)$. Myalgia and weakness as the general first presentation of vital infections was reported in most cases (8/10). Gastrointestinal symptoms, including nausea/ vomiting, diarrhea, anorexia, and abdominal pain, were reported in 5 cases, and the other 5 cases had predominant respiratory symptoms. Three cases had no evidence of respiratory symptoms.
In blood cell count, 3 cases had thrombocytopenia, 2 cases leucopenia, 2 cases anemia, 2 cases bicytopenia, and 1 case pancytopenia. ESR, in all cases, was positive, and 9 cases had abnormal CRP. Troponin, in one case, was abnormal, and procalcitonin, in all cases, were normal. Only one case had normal LDH (1/10), 6 cases had normal AST, and 3 cases had normal ALT. CPK was abnormal in 3 cases. In HRCT assessment, all cases had an abnormal parenchymal pattern, and 9 cases presented the usual pattern of COVID-19 (bilateral multifocal GGO/consolidation) (Fig. 1).

\section{Discussion}

In this case series, we reported 10 cases of RA with serologically approved COVID-19. Almost all physical symptoms and paraclinical features were similar to previous reports in RA cases and also normal healthy individuals. It was approved that COVID-19 in immunesuppressed cases, such as diabetic, rheumatologic cases, and who are receiving immune suppressants such as corticosteroids is more severe [7, 8].

The reported range of incidence of positive PCR-confirmed cases of COVID-19 is surprisingly wide, being reported between 57 per million in China and about 4000 per million in Belgium [9]. Cultural and governmental disciplines have a critical role in this variability. Similarly, the mortality rate of COVID-19 is greatly wide; the highest mortality rates are being reported by Italy as $13.1 \%$ and South Korea as $2.1 \%$, besides the lowest rates by Bahrain and Singapore as 0.3 and $0.4 \%$, respectively [9]. As previously reported, higher age, multi-organ dysfunction, and impaired laboratory markers,

Table 1 Demographic and clinical data

\begin{tabular}{|c|c|c|c|c|c|c|c|}
\hline $\begin{array}{l}\mathrm{No} / \\
\mathrm{sex}\end{array}$ & Comorbid. & Age (duration) & Cortico. (P) & Others & $\mathrm{Cho} / \mathrm{Hx}$ & Complaint, Ph.Exam & Final \\
\hline $1 \mathrm{~F}$ & DM, HTN & $68(7)$ & $5(\mathrm{mg} / \mathrm{d})$ & $\begin{array}{l}\text { MTX }(20 \mathrm{mg} / \mathrm{W}) \\
\text { Sul.(500 mg/D) }\end{array}$ & - & Dry cough, myalgia, weakness & Dis \\
\hline $2 \mathrm{~F}$ & DM, HTN & $58(3)$ & $\begin{array}{l}0.6 \\
(\mathrm{mg} / \mathrm{d})\end{array}$ & Sul. $(500 \mathrm{~m} / \mathrm{BD})$ & - & $\begin{array}{l}\text { Dry cough, dyspnea, chill and fever, } \\
\text { diarrhea, nausea }\end{array}$ & Dis \\
\hline $3 \mathrm{~F}$ & - & $56(3)$ & $5(\mathrm{mg} / \mathrm{D})$ & MTX $(10 \mathrm{mg} / \mathrm{W})$ & - & Dry cough, fever, myalgia & Dis \\
\hline $4 \mathrm{~F}$ & - & $58(4)$ & $5(\mathrm{mg} / \mathrm{D})$ & MTX (10 mg/W) & $\mathrm{Hx}(200 \mathrm{mg} / \mathrm{D})$ & Dyspnea, chill and fever, diaphoresis & Dis \\
\hline $5 \mathrm{M}$ & HTN, CAD & $67(3)$ & $5(\mathrm{mg} / \mathrm{D})$ & $\begin{array}{l}\text { MTX }(7.5 \mathrm{mg} / \mathrm{W}) \\
\text { Sul.(1 g/D) }\end{array}$ & Hx (200 mg/D) & Weakness, nausea & Dis \\
\hline $6 \mathrm{~F}$ & - & $47(10)$ & $2.5(\mathrm{mg} / \mathrm{D})$ & MTX (10 mg/W) & - & Dry cough, dyspnea, chill and fever, myalgia & Dis \\
\hline $7 \mathrm{~F}$ & DM, HTN, CAD & $80(14)$ & $5(\mathrm{mg} / \mathrm{d})$ & Sul. (2 G/BD) & - & Dyspnea, chill and fever, myalgia, anorexia & Dis \\
\hline $8 \mathrm{~F}$ & - & $59(3)$ & - & AZA (50 mg/BD) & Hx (200 mg/d) & Myalgia, anorexia, diarrhea & Dis \\
\hline $9 \mathrm{~F}$ & CAD & $57(6)$ & - & $\mathrm{AZA}(50 \mathrm{mg} / \mathrm{BD})$ & - & Dyspnea, fever, myalgia & Dis \\
\hline $10 \mathrm{~F}$ & HTN, CAD & $67(20)$ & - & - & Hx (200 mg/d) & Fever, myalgia, nausea, weakness & Dis \\
\hline
\end{tabular}

$F$ female, $M$ male, Comorbid comorbidities, HTN hypertension, DM diabetes mellitus, Ph.Exam physical examination, Lab Data laboratory data, $P$ prednisolone, Sul. sulfasalasin, Cho chloroquine, $H x$ hydroxychloroquine, $C R P$ C-reactive protein, ESR estimated sedimentation rate (ESR), B/M bilateral/multifocal, $G G O$ ground-glass opacities, Con. consolidation, Dis discharge with suitable condition, $M$ milligram, $B D$ twice daily 
Table 2 Paraclinical data

\begin{tabular}{|c|c|c|c|c|c|c|c|}
\hline \multirow[t]{2}{*}{ Case No } & \multicolumn{4}{|l|}{ Lab data } & \multicolumn{3}{|c|}{ Radiologic findings } \\
\hline & $\mathrm{CBC}$ & $\begin{array}{l}\text { Inflam. } \\
\text { CRP/ESR }\end{array}$ & Others (only remarkable) & Trop/Procal & $\begin{array}{l}\text { Uni/bilateral } \\
\text { Multi/unifocal }\end{array}$ & Pattern & Other \\
\hline $1 \mathrm{~F}$ & NL. (Plt: 189) & $\begin{array}{l}\text { CRP: } 21 \\
\text { ESR: } 27\end{array}$ & $\begin{array}{l}\text { LDH; 918, AST: 142, } \\
\text { ALT: } 217, \text { CPK: } 201\end{array}$ & NL & $\mathrm{B} / \mathrm{M}$ & Mixed GGO/Con & Linear opacities \\
\hline $2 \mathrm{~F}$ & $\begin{array}{l}\text { WBC: } 2.5 \\
\quad(\text { Lymp: } 30 \%) \\
\text { Plt: } 150\end{array}$ & $\begin{array}{l}\text { CRP: } 14 \\
\text { ESR: } 37\end{array}$ & $\begin{array}{l}\text { LDH; } 577, A S T: 29 \\
\text { ALT: } 56, \text { CPK: } 112\end{array}$ & NL & $\mathrm{B} / \mathrm{M}$ & GGO & - \\
\hline $3 \mathrm{~F}$ & NL (Plt: 160) & $\begin{array}{l}\text { CRP: } 26 \\
\text { ESR: } 41\end{array}$ & $\begin{array}{l}\text { LDH; 725, AST: } 31, \\
\text { ALT: 40, CPK: } 295\end{array}$ & NL & $\mathrm{B} / \mathrm{M}$ & GGO & - \\
\hline $4 \mathrm{~F}$ & NL (Plt: 216) & $\begin{array}{l}\text { CRP: } 11 \\
\text { ESR: } 30\end{array}$ & $\begin{array}{l}\text { LDH; 538, AST: } 27, \\
\text { ALT: } 86, \text { CPK: } 133\end{array}$ & NL & $\mathrm{B} / \mathrm{M}$ & GGO & - \\
\hline $5 \mathrm{~F}$ & $\begin{array}{l}\text { Lymphopenia } \\
\text { (10\%) (Plt: 181) }\end{array}$ & $\begin{array}{l}\text { CRP: } 16 \\
\text { ESR: } 40\end{array}$ & $\begin{array}{l}\text { LDH; 693, AST: } 1117, \\
\text { ALT: 734, CPK: } 192\end{array}$ & NL & $\mathrm{B} / \mathrm{M}$ & Mixed GGO/CP & Linear opacities/reverse halo \\
\hline $6 \mathrm{~F}$ & NL (Plt: 363) & $\begin{array}{l}\text { CRP: } 5.5 \\
\text { ESR: } 32\end{array}$ & $\begin{array}{l}\text { LDH; } 632, \text { AST: } 24, \\
\text { ALT: } 49, \text { CPK: } 42\end{array}$ & $0.14 / \mathrm{NL}$ & $\mathrm{B} / \mathrm{M}$ & Mixed GGO/Con & - \\
\hline $7 \mathrm{~F}$ & $\begin{array}{l}\text { Anemia (Hb:10.7), } \\
\text { (Plt: 134) }\end{array}$ & $\begin{array}{l}\text { CRP: } 23 \\
\text { ESR: } 30\end{array}$ & $\begin{array}{l}\text { LDH; 556, AST: } 27, \\
\text { ALT: } 34, \text { CPK: } 19\end{array}$ & NL & $\mathrm{B} / \mathrm{M}$ & Consolidation & Linear Opacities/reverse halo \\
\hline $8 \mathrm{~F}$ & NL (Plt: 404) & $\begin{array}{l}\text { CRP: } 10 \\
\text { ESR: } 42\end{array}$ & $\begin{array}{l}\text { LDH; 587, AST:69, } \\
\text { ALT: 77, CPK: } 50\end{array}$ & NL & $\mathrm{B} / \mathrm{M}$ & Consolidation & Linear opacities/reverse halo \\
\hline $9 \mathrm{~F}$ & NL (Plt: 327) & $\begin{array}{l}\text { CRP: } 44 \\
\text { ESR: } 50\end{array}$ & NL & NL & $\mathrm{B} / \mathrm{M}$ & GGO & - \\
\hline $10 \mathrm{~F}$ & $\begin{array}{l}H b: 5.7, W B C: 2.2 \\
\quad \text { (lymph: 59\%) } \\
\quad \text { (Plt: 64) }\end{array}$ & $\begin{array}{l}\text { CRP: } 3.3 \\
\text { ESR: } 125\end{array}$ & $\begin{array}{l}\text { LDH; 983, AST:69, } \\
\text { ALT: 96, CPK: } 83\end{array}$ & NL & $\mathrm{B} / \mathrm{M}$ & $\begin{array}{l}\text { Linear } \\
\text { opacities/LAP } \\
\text { /pericardial eff. }\end{array}$ & Linear opacities/LAP \\
\hline
\end{tabular}

such as D-dimer, have a significant role in higher mortality rates [10]. Generally, it is declared that immune-suppressed cases, such as corticosteroid receiving ones, are at higher risk of a severe form of COVID-19; however, it is not completely clear if patients with rheumatoid arthritis, who do not receive immune suppressor, are also at risk or not [11]. Nevertheless, what is clear is that cases with comorbidities, especially with a history of lung disorders, have a higher risk of mortality [11].

In cases with rheumatologic diseases, some hypothetic risk factors of mortality and morbidity, such as lung abnormalities, received immune suppressor, higher age, and organ/ multiorgan damages, were potentially considered [12].

Table 3 Follow-up and treatment data

\begin{tabular}{|c|c|c|c|c|}
\hline \multirow{2}{*}{$\begin{array}{l}\text { Case } \\
\text { No }\end{array}$} & \multicolumn{3}{|l|}{ Treatment } & \multirow{2}{*}{$\begin{array}{l}\text { Follow-up } \\
\text { Duration of } \\
\text { hospitalization }\end{array}$} \\
\hline & $\begin{array}{l}\text { Ventilator/ } \\
\text { ICU }\end{array}$ & $\begin{array}{l}\text { Rheum medication during } \\
\text { hospitalization }\end{array}$ & COVID-19 medication & \\
\hline $1 \mathrm{~F}$ & $-1-$ & Continue & Meropenem/Kaletra/azythromycine & 5 \\
\hline $2 \mathrm{~F}$ & $-1-$ & $\begin{array}{l}\text { Continue/prednisolone increase } \\
\text { until } 20 \mathrm{mg} / \mathrm{d}\end{array}$ & Meropenem/HCQ & 12 \\
\hline $3 \mathrm{~F}$ & $-1-$ & Continue & $\begin{array}{l}\text { Meropenem/levofloxacine/Kaletra/methylprednisolone/plasma } \\
\text { therapy }\end{array}$ & 16 \\
\hline $4 \mathrm{~F}$ & $-1-$ & Continue & Methylprednisolone/Kaletra & 6 \\
\hline $5 \mathrm{~F}$ & $+/+$ & Only MTX discontinued & $\begin{array}{l}\text { Methylprednisolone/azythromycine/HCQ/plasma } \\
\text { therapy/ASA/heparin }\end{array}$ & 30 \\
\hline $6 \mathrm{~F}$ & $-1-$ & Continue & Azythromycine/HCQ/prednisolone & 10 \\
\hline $7 \mathrm{~F}$ & $-1-$ & Continue & Levofloxacin/azythromycine/Kaletra/plasma therapy & 1.5 \\
\hline $8 \mathrm{~F}$ & $-1-$ & Continue & Azythromycine/Kaletra/ribavirin & 11 \\
\hline $9 \mathrm{~F}$ & $-1-$ & Continue & Meropenem/levofloxacin/Kaletra & 6 \\
\hline $10 \mathrm{~F}$ & $-1-$ & Continue & Tamiflu/HCQ/naproxen & 5 \\
\hline
\end{tabular}

Kaletra (lopinavir-ritonavir), $H C Q$ hydroxychloroquine, $A S A$ aspirin, $M T X$ metotroxate 

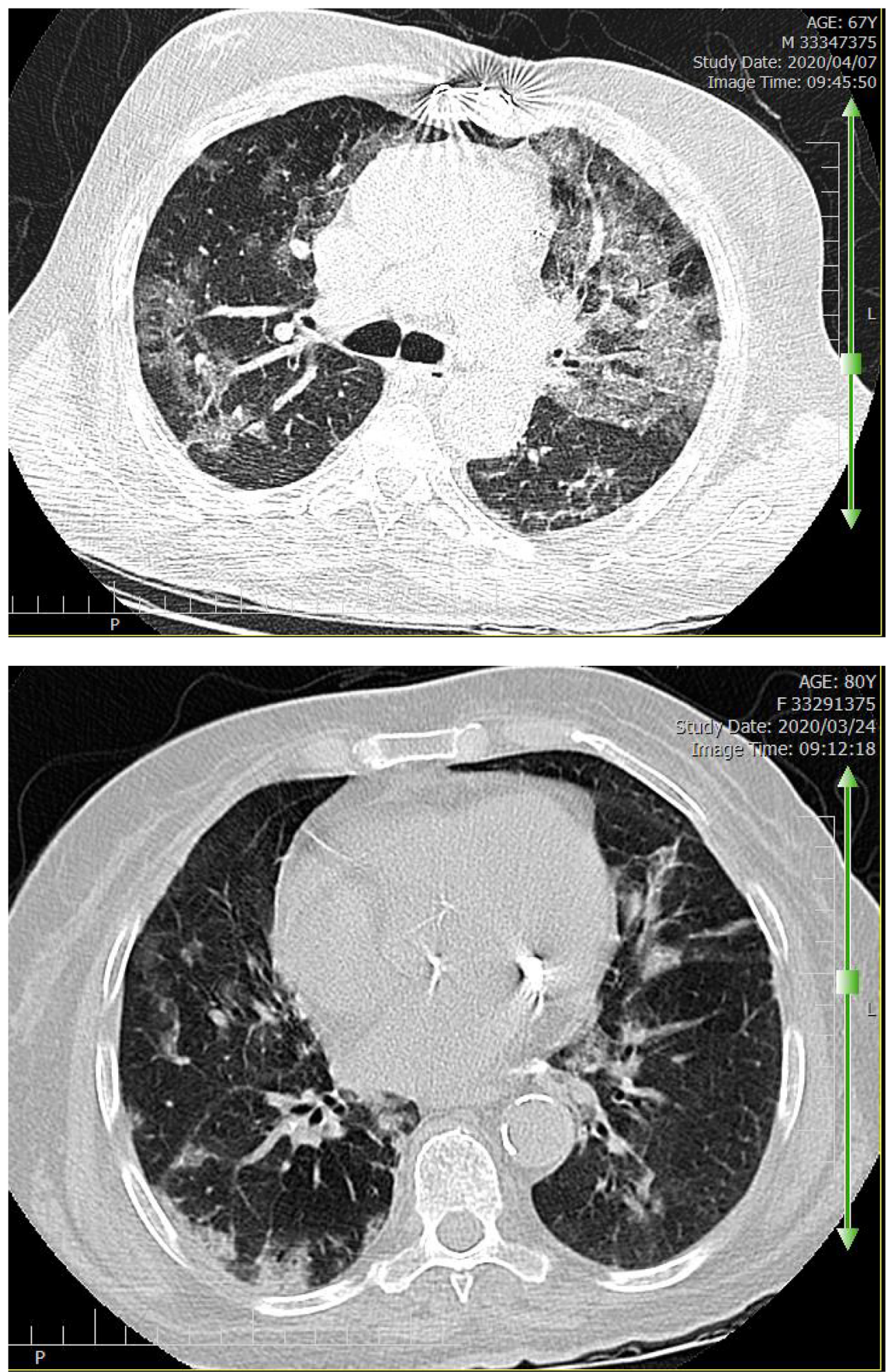

Fig. 1 Multilobar bilateral GGo in two mentioned cases. a Case 5, b case 7

However, mortality and morbidity in these cases were not widely assessed, and contrary to initial reports warned about higher mortality in immune-suppressed patients, recent publications confirmed that immune-suppressed cases had similar or even less mortality rate versus normal population. These can be since the host immune response, the main driver of lung tissue damage, is impaired in immune-suppressed cases $[13,14]$. On the other hand, it is not clear that if immunesuppressed cases, who previously had organ damage (e.g., renal injuries or lung parenchymal abnormalities), have a 
higher rate of mortality/morbidity or not (versus cases with the normal immune system).

Moreover, medications have a significant role in the outcomes of cases with immune system dysfunction, such as rheumatologic diseases. Monti et al., in a brief report about 13 cases of RA and spondyloarthritis, declared that none of their cases progress to severe pulmonary complications, and only one case was hospitalized. Although Monti et al., due to the small size of the sample, described that "our findings do not allow any conclusions on the incidence rate of SARSCoV-2 infection in patients with rheumatic diseases, nor on the overall outcome of immunocompromised patients affected by COVID-19" [4].

Monti et al. had 4 PCR confirmed cases, 4 clinically suspected for COVID-19, and 5 with the positive past medical history of positive case exposure, while we had 10 patients with both PCR and radiological confirmation for COVID-19. Similarly, fatigue, myalgia, dry cough, and fever were reported in most cases.

In another report, Haberman et al. assessed patients with known "immune-mediated inflammatory disease (RA, psoriatic arthritis, ankylosing spondylitis, psoriasis, inflammatory bowel disease, or related conditions) who were receiving anticytokine biologics, other immunomodulatory therapies, or both when confirmed or highly suspected symptomatic COVID-19 developed." They found that hospitalization in RA cases, which was the most frequent disease in hospitalized cases, commonly occurred in cases with comorbidities, such as hypertension, diabetes, or chronic obstructive pulmonary disease. They finally concluded that "an incidence of hospitalization among patients with the immune-mediated inflammatory disease was consistent with that among patients with COVID-19 in the general population." [15] In contrast, they reported fever and cough as the most common symptoms; they did not report myalgia and weakness in their cases. Moreover, there was no data about the patient's radiologic features.

SLE, as another rheumatologic disease, was studied by Sawalha et al. They aimed to assess epigenetic dysregulation of ACE2 and interferon-regulated genes demethylation; they concluded that "lupus patients are more prone to SARS-CoV-2 infections and complicated disease course of COVID-19." Finally, as a target, controlling the ACE2 gene was recommended for the prevention and therapy of COVID-19 [16].

Cheng et al. reported 5 cases of RA/systemic sclerosis with COVID-19, and they described the clinical characteristics. Cough and fever were the most common symptoms, and fatigue was reported in one case. Leukopenia and lymphopenia in 2 patients were seen. In our report, leucopenia was seen in 2 patients and lymphopenia in one patient; however, thrombocytopenia was the most laboratory abnormality inconsistent with normal populations [2].
Although only 3 patients of them had increased CRP, almost all cases had abnormal CRP and ESR in our report. Some other inflammatory markers, such as IL $6 / 10$, were evaluated in the mentioned report, while we assessed troponin and procalcitonin, finding it unuseful. Similarly, all their cases in both studies had abnormal imaging findings, most commonly GGo/consolidation opacities. Three patients progressed to a more severe stage of COVID-19.

Regarding the pathogenic mechanisms of COVID-19 known so far, overactivation of the immune system may have a critical role in the severe stage, and in rheumatologic cases, due to native immune deficiency situation, the severe symptoms may be uncommonly presented $[17,18]$.

There are several laboratory biomarkers, which constantly are suggested for diagnosis and prognosis of COVID-19, such as interleukins (IL-6 and IL 10), ferritin, WBC count, platelet count, together with LDH and liver function test. These laboratory biomarkers also frequently are seen abnormal in this report [19].

Radiologic features, in these reported cases, are also similar to the normal population. In this and the previous reports on normal cases, bilateral multifocal GGO is the most frequent finding in lung HRCT of COVID-19 [12]; this finding is in line with Ye et al.'s results of 4 cases of RA [20].They also mention that respiratory failure is common in cases; this is not seen in our case series with at least 2 times more sample size.

On the other hand, dose adjustment of immune suppressive and immune-modulatory medications in rheumatologic cases has been previously recommended; however, in our reports, these cases are shown to have more unusual symptoms of COVID-19 against the normal population in addition to uncommonly progress to severe stage.

This theory is suggested based on the main pathology of the severe immune response in critical cases of COVID-19, suggesting that uncontrolled immune response such as cytokine storm has a key role in the progressing stage of COVID-19 $[21,22]$. Therefore, immune modulation is suggested for future options in critically ill cases. DMARDS and other immune cells' regulatory medications, such as tocilizumab and cytokine blood filtration, are presented as promising treatment options; however, their efficacy in all cases is still unclear [21,23].

Further evaluations on the role of immune regulatory medications and innate immune systems in the activity and progression of the COVID-19 in rheumatologic disease cases are recommended.

Acknowledgments We would like to thank the nurses and other Baqiyatallah Hospital personnel for the cooperation in collecting the cases' data.

\section{Compliance with ethical standards}

Disclosures None. 


\section{References}

1. Feng Y, Ling Y, Bai T, Xie Y, Huang J, Li J, Xiong W, Yang D, Chen R, Lu F, Lu Y, Liu X, Chen Y, Li X, Li Y, Summah HD, Lin H, Yan J, Zhou M, Lu H, Qu J (2020) COVID-19 with different severities: a multicenter study of clinical features. Am J Respir Crit Care Med 201(11):1380-1388. https://doi.org/10.1164/rccm. 202002-0445OC

2. Cheng C, Li C, Zhao T, Yue J, Yang F, Yan Y, Liu X (2020) COVID-19 with rheumatic diseases: a report of 5 cases. Clin Rheumatol 39(7):2025-2029. https://doi.org/10.1007/s10067-02005160-x

3. Song J, Kang S, Choi SW, Seo KW, Lee S, So MW, Lim DH (2020) Coronavirus disease 19 (COVID-19) complicated with pneumonia in a patient with rheumatoid arthritis receiving conventional disease-modifying antirheumatic drugs. Rheumatol Int 40(6): 991-995. https://doi.org/10.1007/s00296-020-04584-7

4. Monti S, Balduzzi S, Delvino P, Bellis E, Quadrelli VS, Montecucco C (2020) Clinical course of COVID-19 in a series of patients with chronic arthritis treated with immunosuppressive targeted therapies. Ann Rheum Dis 79(5):667-668. https://doi. org/10.1136/annrheumdis-2020-217424

5. Bozzalla Cassione E, Zanframundo G, Biglia A, Codullo V, Montecucco C, Cavagna L (2020 :annrheumdis-2020-217717) COVID-19 infection in a northern-Italian cohort of systemic lupus erythematosus assessed by telemedicine. Ann Rheum Dis 79: 1382-1383. https://doi.org/10.1136/annrheumdis-2020-217717

6. Ehrenfeld M, Tincani A, Andreoli L, Cattalini M, Greenbaum A, Kanduc D, Alijotas-Reig J, Zinserling V, Semenova N, Amital H, Shoenfeld Y (2020) Covid-19 and autoimmunity. Autoimmun Rev 19(8):102597-102597. https://doi.org/10.1016/j.autrev.2020. 102597

7. Zhong J, Shen G, Yang H, Huang A, Chen X, Dong L, Wu B, Zhang A, Su L, Hou X, Song S, Li H, Zhou W, Zhou T, Huang Q, Chu A, Braunstein Z, Rao X, Ye C, Dong L (2020) COVID-19 in patients with rheumatic disease in Hubei province, China: a multicentre retrospective observational study. Lancet Rheumatol 2(9):e557-e564. https://doi.org/10.1016/s2665-9913(20)30227-7

8. Holman N, Knighton P, Kar P, O'Keefe J, Curley M, Weaver A, Barron E, Bakhai C, Khunti K, Wareham NJ, Sattar N, Young B, Valabhji J (2020) Risk factors for COVID-19-related mortality in people with type 1 and type 2 diabetes in England: a populationbased cohort study. Lancet Diabetes Endocrinol. https://doi.org/10. 1016/s2213-8587(20)30271-0

9. Al-Tawfiq JA, Leonardi R, Fasoli G, Rigamonti D (2020) Prevalence and fatality rates of COVID-19: what are the reasons for the wide variations worldwide? Travel Med Infect Dis:101711. https://doi.org/10.1016/j.tmaid.2020.101711

10. Zhou F, Yu T, Du R, Fan G, Liu Y, Liu Z, Xiang J, Wang Y, Song B, Gu X, Guan L, Wei Y, Li H, Wu X, Xu J, Tu S, Zhang Y, Chen H, Cao B (2020) Clinical course and risk factors for mortality of adult inpatients with COVID-19 in Wuhan, China: a retrospective cohort study. Lancet 395(10229):1054-1062. https://doi.org/10. 1016/S0140-6736(20)30566-3
11. Pope JE (2020) What does the COVID-19 pandemic mean for rheumatology patients? Curr Treatm Opt Rheumatol 6:1-4 https://doi.org/10.1007/s40674-020-00145-y

12. Huang C, Wang Y, Li X, Ren L, Zhao J, Hu Y, Zhang L, Fan G, Xu J, Gu X, Cheng Z, Yu T, Xia J, Wei Y, Wu W, Xie X, Yin W, Li H, Liu M, Xiao Y, Gao H, Guo L, Xie J, Wang G, Jiang R, Gao Z, Jin Q, Wang J, Cao B (2020) Clinical features of patients infected with 2019 novel coronavirus in Wuhan, China. Lancet 395(10223):497506

13. D'Antiga L (2020) Coronaviruses and immunosuppressed patients: the facts during the third epidemic. Liver Transpl 26(6):832-834. https://doi.org/10.1002/lt.25756

14. Tannuri U, Tannuri ACA, Cordon MNA, Miyatani HT (2020) Low incidence of COVID-19 in children and adolescent post-liver transplant at a Latin American reference center. Clinics (Sao Paulo, Brazil) 75:e1986. https://doi.org/10.6061/clinics/2020/e1986

15. Haberman R, Axelrad J, Chen A, Castillo R, Yan D, Izmirly P, Neimann A, Adhikari S, Hudesman D, Scher JU (2020) Covid-19 in immune-mediated inflammatory diseases - case series from New York. N Engl J Med 383:85-88. https://doi.org/10.1056/ NEJMc2009567

16. Sawalha AH, Zhao M, Coit P, Lu Q (2020) Epigenetic dysregulation of ACE2 and interferon-regulated genes might suggest increased COVID-19 susceptibility and severity in lupus patients. Clin Immunol 215(108410):8

17. Yazdanpanah F, Hamblin MR, Rezaei N (2020) The immune system and COVID-19: friend or foe? Life Sci 256:117900. https://doi. org/10.1016/j.1fs.2020.117900

18. Paces J, Strizova Z, Smrz D, Cerny J (2020) COVID-19 and the immune system. Physiol Res 69:379-388

19. Henry BM, de Oliveira MHS, Benoit S, Plebani M, Lippi G (2020) Hematologic, biochemical and immune biomarker abnormalities associated with severe illness and mortality in coronavirus disease 2019 (COVID-19): a meta-analysis. Clin Chem Lab Med 58(7): 1021-1028. https://doi.org/10.1515/cclm-2020-0369

20. Ye C, Cai S, Shen G, Guan H, Zhou L, Hu Y, Tu W, Chen Y, Yu Y, Wu X, Zhong J, Dong L (2020) Clinical features of rheumatic patients infected with COVID-19 in Wuhan, China. Ann Rheum Dis 22(217627):2020-217627

21. Zhong J, Tang J, Ye C, Dong L (2020) The immunology of COVID-19: is immune modulation an option for treatment? Lancet Rheumatol 2(7):e428-e436. https://doi.org/10.1016/s26659913(20)30120-x

22. Coperchini F, Chiovato L, Croce L, Magri F, Rotondi M (2020) The cytokine storm in COVID-19: an overview of the involvement of the chemokine/chemokine-receptor system. Cytokine Growth Factor Rev 53:25-32. https://doi.org/10.1016/j.cytogfr.2020.05. 003

23. Al Shareef K, Bakouri M (2020) Cytokine blood filtration responses in COVID-19. Blood Purif:1-9. https://doi.org/10.1159/ 000508278

Publisher's note Springer Nature remains neutral with regard to jurisdictional claims in published maps and institutional affiliations. 